\title{
Familial Adrenal Gland Pheochromocytoma
}

National Cancer Institute

\section{Source}

National Cancer Institute. Familial Adrenal Gland Pheochromocytoma. NCI Thesaurus. Code C157248.

A familial adrenal gland pheochromocytoma caused by mutations in SDHB, SDHC, and SDHD genes. 